\title{
Active surveillance of canine visceral leishmaniasis and american trypanossomiasis in rural dogs from non endemic area
}

Vigilância da leishmaniose visceral e da tripanossomíase americana em cães de área rural indene

Rozeani Olimpio Tome ${ }^{1 *}$; Fernanda Conceiçáo Gaio ${ }^{1}$; Diego Generoso²; Benedito Donizete Menozzi²; Helio Langoni ${ }^{3}$

\begin{abstract}
${ }^{1}$ Ex Residente do Laboratório de Diagnóstico de Zoonoses, Departamento de Higiene Veterinária e Saúde Pública, Faculdade de Medicina Veterinária e Zootecnia, Universidade Estadual Paulista - UNESP

${ }^{2}$ Laboratório de Diagnóstico de Zoonoses, Departamento de Higiene Veterinária e Saúde Pública, Faculdade de Medicina Veterinária e Zootecnia, Universidade Estadual Paulista - UNESP

${ }^{3}$ Departamento de Higiene Veterinária e Saúde Pública, Faculdade de Medicina Veterinária e Zootecnia, Universidade Estadual Paulista - UNESP

Received May 27, 2010

Accepted July 7, 2010
\end{abstract}

\begin{abstract}
The canine visceral leishmaniasis (CVL) and american trypanosomiasis are important zoonoses in public health and dogs are the main domestic reservoir of the parasite for humans. The goal of this study was to estimate the prevalence of circulating antibodies anti-Trypanosoma cruzi and anti-Leishmania sp. in sera of dogs from the rural area of Botucatu, SP, Brazil. During the annual vaccination campaign against canine rabies in rural area, 689 blood samples were taken and processed by indirect immunofluorescent antibody test. The serological tests revealed the absence of antibodies anti-Leishmania spp., but anti-T. cruzi antibodies were detected in $3(0.4 \%)$ dogs.
\end{abstract}

Keywords: Dogs, Chagas disease, indirect immunofluorescence, leishmaniasis.

\section{Resumo}

A leishmaniose visceral canina (LVC) e a tripanossomíase americana são importantes zoonoses para a saúde pública que encontram no cáo o principal reservatório doméstico para o homem. O trabalho procurou estimar a prevalência de anticorpos circulantes anti-Trypanosoma cruzi e anti-Leishmania spp., em amostras de cáes provenientes da zona rural do município de Botucatu, SP. Durante a campanha de vacinação antirrábica canina da zona rural do município, foram coletadas 689 amostras de soro e processadas pela técnica de imunofluorescência indireta. Os testes sorológicos revelaram a ausência de anticorpos anti-Leishmania spp. e, na pesquisa dos anticorpos anti-T. cruzi, foram detectados $3(0,4 \%)$ cáes.

Palavras-chave: Cáes, doença de Chagas, imunofluorescência indireta, leishmaniose.

Canine visceral leishmaniasis has been one of the most important emerging zoonoses from a public health point of view in the State of São Paulo, since the confirmation of its autochthonous status in 1998. Until that time, there had been no records of its occurrence (SÃO PAULO, 2006). It is caused by the protozoon Leishmania spp. and is transmitted through the bites of infected female phlebotomines. Dogs form a domestic reservoir that plays the role of a source of immediate infection for humans in urban environments (WERNECK et al., 2008).

\footnotetext{
${ }^{*}$ Corresponding author: Rozeani Olimpio Tome

Médica Veterinária, Rua Santa Catarina, 17, Vila Progresso,

CEP 13.202-150, Jundiaí - SP, Brazil;

e-mail: olimpio_vet@yahoo.com.br
}

The presence of the disease in a given region has been correlated with the presence of serologically positive dogs, which confirms that dogs are an individual risk factor for householders (BORGES et al., 2008). In addition to dogs, wild animals like foxes and marsupials are reservoirs and, because of their synanthropic habits, they may promote a link between the wild and domestic cycles (GONTIJO; MELO, 2004).

American trypanosomiasis, also known as Chagas disease, is a disease transmitted by the insect vector known as the barbeiro, which belongs to the subfamily Triatominae (KROPF et al., 2000).

Studiers on the role of dogs in transmitting Chagas disease are still scarce, but the possibility that they may be important cannot be dismissed. Dogs have great potential as reservoirs since 
they come into direct contact with wild reservoirs of the disease (MAYWALD et al., 1996; LUCHEIS et al., 2005).

The present study had the aim of estimating the occurrence of anti-Trypanosoma cruzi and anti-Leishmania spp. antibodies in serum from dogs in the rural zone of the municipality of Botucatu, SP.

Botucatu is located in the central southern region of the State of São Paulo (latitude $22.88583^{\circ} \mathrm{S}$ and longitude $48.445^{\circ} \mathrm{W}$ ), at around $805 \mathrm{~m}$ above sea level, and covers an area of $1,483 \mathrm{~km}^{2}$, of which $1,329 \mathrm{~km}^{2}$ corresponds to the rural zone and $154 \mathrm{~km}^{2}$ to the urban zone. Native vegetation covers $10.45 \%$ of this total area. The total population of Botucatu is 130,348 inhabitants (IBGE, 2009) and the canine population of the municipality was estimated to be 29,788 animals in 2009 (INSTITUTO PASTEUR, 2009). The region's climate is humid subtropical, with dry winters and hot summers. The mean temperature is $22^{\circ} \mathrm{C}$ and the mean rainfall is $1,250 \mathrm{~mm}$. In winter, it is rare for the temperature to fall below $2{ }^{\circ} \mathrm{C}$ (BOTUCATU, 2009).

The area continues to be free from the disease, possibly because the transmitting vector Lutzomyia longipalpis is absent or because the climatic situation, altitude or other factors do not favor vector maintenance. On the other hand, imported cases have been diagnosed (LANGONI et al., 2001; TRONCARELLI et al., 2009).

During the annual anti-rabies vaccination campaign among dogs in the rural zone of the municipality of Botucatu in 2009, blood samples of 2 to $5 \mathrm{~mL}$ were taken from 689 dogs by means of jugular or cephalic venous puncture. The samples were centrifuged and the serous fraction was stored at $-20^{\circ} \mathrm{C}$ until processing in the laboratory of the Zoonosis Research Group (NUPEZO) of the Department of Veterinary Hygiene and Public Health, UNESP, Botucatu. To perform the examinations, the serum samples were prepared as dilutions of 1:20 to 1:320, in flat-bottomed microplates. These were then subjected to the indirect immunofluorescence reaction (IIR), to detect class IgG antibodies, in accordance with the standardized technique described by Camargo (1964). Anti-IgG canine conjugate was used, kindly donated by the Zoonosis Control Center of São Paulo, along with slides for immunofluorescence impregnated with antigens for T. cruzi (strain $\mathrm{Y}$ ) and leishmaniasis (Leishmania major) supplied by the NUPEZO laboratory.

Serum samples that were known to be positive or negative through testing using this method were used as controls. Samples that resulted in fluorescence, including in membranes and flagella, were considered to be positive. Those that presented absence of brilliance, i.e. remaining with a red or brown coloration, were taken to be negative. The readings were made under a Zeiss SH250 immunofluorescence microscope. Samples with titers greater than or equal to $1: 40$ were considered to be positive in cases of leishmaniasis and 1:20, in cases of T. cruzi.

Among the 689 animals evaluated, $56.60 \%$ were males, 9.14\% were castrated, $73.29 \%$ were between one and five years of age and $73.59 \%$ were mongrels.

From the investigation of anti-T. cruzi antibodies, three animals were found to be positive (0.4\%): all of them were mongrels and over the age of one year. None of these animals presented any signs suggestive of the disease, such as lethargy, anorexia, intolerance to exercise, pallid mucosa, hepatomegaly, splenomegaly, neurological signs or ascites.
From the investigation of circulating anti-Leishmania sp. antibodies, none were detected under the conditions of the present study, i.e. there were no positive animals among the 689 serum samples tested.

These results relating to canine leishmaniasis confirm previous studies that concluded that the disease did not yet constitute a problem in the municipality of Botucatu, SP (LANGONI et al., 2001; CARVALHO, 2007).

According to Souza et al. (2009), the seroprevalence among dogs from rural areas in the State of Mato Grosso do Sul was 45.3\%, out of a total of 75 dogs tested using IIR and $22.7 \%$ using ELISA.

The seroprevalence for T. cruzi among the samples analyzed in the present study was $0.4 \%$, which was lower than what was reported from Botucatu by Lucheis et al. (2005), among dogs whose owners had Chagas disease.

The occurrence of anti-T. cruzi antibodies suggests that this agent is circulating in the area and that dogs may be participating in the epidemiological transmission chain for Chagas disease. The negative result regarding the presence anti-Leishmania antibodies suggests that the municipality remains free from this disease.

\section{References}

BORGES, B. K. A. et al. Avaliação do nível de conhecimento e de atitudes preventivas da população sobre a leishmaniose visceral em Belo Horizonte, Minas Gerais, Brasil. Cadernos de Saúde Pública, v. 24, p. 777-784, 2008.

BOTUCATU. Site oficial. 2009. Disponível em: <http://www.botucatu. sp.gov.br/dadosgerais/>. Acesso em: 23 fev. 2010.

CAMARGO, M. E. Introdução às técnicas de imunofluorescência. Revista Brasileira de Patologia Clínica, v. 10, n. 4, p. 143-169, 1964.

CARVALHO, J. L. B. Leishmaniose visceral canina: busca ativa de casos e estudo sobre o conhecimento da doença em proprietários de cáes na área urbana de Botucatu. 2007. 66 f. Dissertação (Mestrado em Planejamento Animal e Saúde Pública)-Faculdade de Medicina Veterinária e Zootecnia, Universidade Estadual Paulista, Botucatu, 2007.

GONTIJO, C.M.F.; MELO, M.N. Leishmaniose Visceral no Brasil: quadro atual, desafios e perspectivas. Revista Brasileira de Epidemiologia, v.7, n.3, p.338-349, 2004.

INSTITUTO BRASILEIRO DE GEOGRAFIA E ESTATÍSTICA IBGE. Censo demográfico. 2009. Disponível em: <http://www.ibge. gov.br>. Acesso em: 23 fev. 2010.

INSTITUTO PASTEUR. Governo do Estado de Sáo Paulo. Metas para os municípios em 2009. Disponível em: <http://www.pasteur. saude.sp.gov.br/news/ppi2009.asp>. Acesso em: 23 fev. 2010.

KROPF, S. P.; AZEVEDO, N.; FERREIRA, L. O. Doença de Chagas: a construção de um fato científico e de um problema de saúde pública no Brasil. Revista Ciência \& Saúde Coletiva, v. 5, n. 2, p. 347-365, 2000 .

LANGONI, H. et al. Epidemiological vigilance for canine Leishmaniasis in the county of Botucatu, SP, Brazil. Ars. Veterinária, v. 17, n. 3, p. 196-200, 2001. 
LUCHEIS, S. B. et al. Trypanosomatids in dogs belonging to individuals with chronic Chagas disease living in Botucatu town and surrounding region, São Paulo State, Brazil. Journal of Venomous Animals and Toxins including Tropical Diseases, v. 11, n. 4, p. 492-509, 2005.

MAYWALD, P. G. et al. Leishmaniose tegumentar, visceral e doença de Chagas caninas em municípios do Triângulo Mineiro e Alto Paranaíba, Minas Gerais, Brasil. Cadernos de Saúde Pública, v. 12, n. 3, p. 321-328, 1996.

SÃO PAULO (Estado). Secretaria de Estado da Saúde. Superintendência de Controle de Endemias e Coordenadoria de Controle de Doenças. Manual de vigilância e controle da Leishmaniose Visceral Americana do Estado de Sáo Paulo. São Paulo, 2006. 161 p.
SOUZA, A. I. et al. Soroprevalência da infecção por Trypanosoma cruzi em cães de uma área rural do Estado de Mato Grosso do Sul. Revista Pesquisa Veterinária Brasileira, v. 29, n. 2, p. 150-152, 2009.

TRONCARELLI, M. Z. et al. Leishmania spp. and/or Trypanosoma cruzi diagnosis in dogs from endemic and nonendemic areas for canine visceral leishmaniasis. Veterinary Parasitology, v. 164, n. 2-4, p. 118-123, 2009.

WERNECK, G. L. et al. Avaliação da efetividade das estratégias de controle da leishmaniose visceral na cidade de Teresina, Estado do Piauí, Brasil: resultados do inquérito inicial - 2004. Revista Epidemiologia e Serviços de Saúde, v. 17, n. 2, p. 87-96, 2008. 